\title{
Tick-Borne Hemoparasites of Sheep: A Molecular Research in Turkey
}

\author{
Onur Ceylan ${ }^{1,+} \oplus$, Benedicto Byamukama ${ }^{2,+}$, Ceylan Ceylan ${ }^{1}(0)$, Eloiza May Galon ${ }^{2}{ }^{\oplus}$, Mingming Liu $^{2}$, \\ Tatsunori Masatani $^{3}\left(\mathbb{D}\right.$, Xuenan Xuan ${ }^{2, *(D)}$ and Ferda Sevinc $1, * \mathbb{D}$ \\ 1 Department of Parasiyology, Faculty of Veterinary Medicine, Selcuk University, Konya 42250, Turkey; \\ onurceylan@selcuk.edu.tr (O.C.); ceylanilhan@selcuk.edu.tr (C.C.) \\ 2 National Research Center for Protozoan Diseases, Obihiro University of Agriculture and Veterinary Medicine, \\ Obihiro, Hokkaido 080-8555, Japan; benards.benedicto4@gmail.com (B.B.); eloizagalon@gmail.com (E.M.G.); \\ lmm_2010@hotmail.com (M.L.) \\ 3 Faculty of Applied Biological Sciences, Gifu University, Gifu 501-1193, Japan; tatsunorimasatani@gmail.com \\ * Correspondence: gen@obihiro.ac.jp (X.X.); fsevinc@selcuk.edu.tr (F.S.) \\ + These authors contributed equally to this work.
}

Citation: Ceylan, O.; Byamukama, B.; Ceylan, C.; Galon, E.M.; Liu, M.; Masatani, T.; Xuan, X.; Sevinc, F. Tick-Borne Hemoparasites of Sheep: A Molecular Research in Turkey. Pathogens 2021, 10, 162. https:// doi.org/10.3390/pathogens10020162

Academic Editor: Olivier Sparagano

Received: 12 January 2021

Accepted: 2 February 2021

Published: 3 February 2021

Publisher's Note: MDPI stays neutral with regard to jurisdictional claims in published maps and institutional affiliations.

Copyright: (c) 2021 by the authors. Licensee MDPI, Basel, Switzerland. This article is an open access article distributed under the terms and conditions of the Creative Commons Attribution (CC BY) license (https:// creativecommons.org/licenses/by/ $4.0 /)$.
Abstract: Tick-borne diseases (TBDs) indulge in severe economic losses in the livestock industry by adversely affecting the small ruminant breeding in tropical and subtropical zone countries, including Turkey. Turkey encompasses a wide land area representing diverse climatic conditions. The present study explored the presence and distribution of Babesia ovis, Theileria ovis, Theileria lestoquardi, Anaplasma ovis, Anaplasma phagocytophilum and the co-occurrence status of these pathogens. A total of 299 sheep blood samples were collected from fifteen provinces located in six different geographical regions in Turkey. PCR analyses were executed using species-specific primers based on Babesia ovis BoSSU rRNA, Theileria ovis ToSSU rRNA, Theileria lestoquardi 18S rRNA, Anaplasma ovis Major Surface Protein (AoMSP4), and Anaplasma phagocytophilum 16S rRNA genes. Overall, 219 (73.24\%) sheep were found to be infected with at least one of the following protozoan and rickettsial pathogens; $B$. ovis, A. ovis, T. ovis, and A. phagocytophilum. Theileria lestoquardi was not detected in any blood sample. The global prevalence of B. ovis, A. ovis, T. ovis, and A. phagocytophilum was estimated to be $2.68 \%$, $16.05 \%, 41.47 \%$, and $57.19 \%$, respectively. Besides this, dual $(24.41 \%)$, triple $(9.03 \%)$, and quadruple $(0.67 \%)$ co-infections were detected in the study. Phylogenetic analysis revealed significant nucleotide sequence identities between the sequences obtained in this study and the sequences registered in the GenBank. This study provides relevant data regarding the predominance of ovine tick-borne protozoan and rickettsial agents in Turkey. A high molecular prevalence of tick-borne pathogens (TBPs) was identified in the study. This situation indicates that TBPs should be screened continuously, and necessary control measures should be taken to prevent diseases caused by tick-borne protozoan and rickettsial agents.

Keywords: Babesia ovis; Theileria ovis; Anaplasma ovis; Anaplasma phagocytophilum; sheep

\section{Introduction}

In the veterinary field, tick-borne diseases (TBDs) are highly significant [1]. Tickborne hemoprotozoan and rickettsial agents hinder animal production in tropical and subtropical zone countries, including Turkey [2]. These agents negatively affect small ruminant breeding by reducing the yield and causing abortions. This, in turn, leads to serious economic losses in the livestock industry [2-4].

Several hemoparasitic and rickettsial diseases transmitted by vector ticks could infect small ruminants in Europe [5]. Among these, anaplasmosis, babesiosis, and theileriosis are the main TBDs and pose threats to the small ruminant breeding and livestock economy [1]. As in some other countries [6,7], the small ruminant breeding is also one of the primary sources of milk and meat in Turkey, which has a geographically advantageous position 
between Asian and European countries comprising approximately forty million sheep and favorable climatic conditions for vector ticks $[2,8]$.

The most economically significant hemoprotozoan parasites of small ruminants, Babesia spp. and Theileria spp., have worldwide distribution [1]. While ovine babesiosis is responsible for an acute disease characterized by fever, hemolytic anemia, hemoglobinuria, and icterus, ovine theileriosis is characterized by lymphoproliferative disease with high mortality and morbidity. Malignant ovine theileriosis incurs deaths in the Mediterranean region, Middle East, South East Asia, and the Indian subcontinent $[9,10]$. It was detected in Europe [11] and the neighboring countries of Turkey (Iran, Iraq) [12,13]; however, it has not been reported in sheep from Turkey [14].

The species of the genus Anaplasma (Rickettsiales: Anaplasmataceae) are tick-transmitted obligate intracellular microorganisms affecting both human and animal health [10]. Anaplasma centrale, A. marginale, A. bovis, A. ovis, A. platys, and A. phagocytophilum are the most known etiological agents of anaplasmosis [15]. Several Anaplasma species, including A. ovis, A. marginale, and the human granulocytic anaplasmosis (HGA) agent $A$. phagocytophilum, can cause ovine anaplasmosis [10]. It was also reported that $A$. ovis might be a zoonotic rickettsial pathogen [16,17]. Although A. ovis generally cause subclinical infections in sheep, severe diseases characterized by hemolytic anemia can occur in stressful conditions [18]. Anaplasma phagocytophilum, formerly known as Ehrlichia phagocytophila and E. equi, is particularly transmitted by Ixodes ricinus and causes tick-borne fever (TBF) with symptoms including fever, anorexia, dullness, and sudden drop in milk yield in domestic ruminants. Reduced weight gain, abortions, and fertility disorders have also been documented $[3,4,19]$.

Several molecular studies regarding ovine TBDs were conducted in Turkey [20-23]. However, most of these studies geographically restricted to only one region or province. Aouadi et al. [6] and Ringo et al. [24] stated that studies including larger sample size and wider geographical areas could provide deeper insights regarding the actual prevalence and economic importance of tick-borne pathogens (TBPs). Therefore, the aim of this study was the molecular survey of tick-borne hemoprotozoan and rickettsial agents leading to various economically significant yield losses such as meat, milk, manure, skin, and wool in Turkish small ruminants grazing in fifteen different provinces, with some agents being zoonotic as well.

\section{Results}

\subsection{Overall Infection Rates}

The present study screened 299 sheep for ovine tick-borne hemoprotozoan and rickettsial agents by molecular techniques. Overall, 219 (73.24\%) of the 299 sheep were found to be positive. The overall prevalences of B. ovis, T. ovis, A. ovis, and A. phagocytophilum were identified as $2.68 \%, 41.47 \%, 16.05 \%$, and $57.19 \%$, respectively. T. lestoquardi DNA was not found in the samples of the present study. Detailed molecular prevalences according to the provinces are outlined in Table 1.

\subsection{Co-Infections Detected in the Study}

The co-infection rate was estimated to be $46.58 \%$ (n: 102) of the total infection number (n: 219$)$. Three types of coinfections (dual $(24.41 \%, \mathrm{n}: 73)$, triple $(9.03 \%, \mathrm{n}: 27)$, and quadruple $(0.67 \%$, n: 2)) were reported in the study. Dual co-infections $(71.57 \%)$ were found to be the most prevalent among the co-infection cases, followed by triple co-infections $(26.47 \%)$ and quadruple co-infections $(1.96 \%)$, respectively. Dual, triple, and quadruple co-infections were observed to occur in nine different ways (B. ovis + T. ovis, B. ovis + A. phagocytophilum, T. ovis + A. ovis, T. ovis + A. phagocytophilum, A. ovis + A. phagocytophilum, B. ovis + T. ovis + A. ovis, B. ovis + T. ovis + A. phagocytophilum, T. ovis + A. ovis + A. phagocytophilum, B. ovis + T. ovis + A. ovis + A. phagocytophilum). Detailed information about co-infections detected in the study is provided in Table 2. 
Table 1. Global prevalence of tick-borne pathogens (TBPs) identified in the study.

\begin{tabular}{cccccc}
\hline & B. ovis & T. ovis & T. lestoquardi & A. ovis & A. phagocytophilum \\
\hline & $\mathrm{n} / \mathrm{N} / \%$ & $\mathrm{n} / \mathrm{N} / \%$ & $\mathrm{n} / \mathrm{N} / \%$ & $\mathrm{n} / \mathrm{N} / \%$ & $\mathrm{n} / \mathrm{N} / \%$ \\
\hline Afyon & $0 / 20 / 0$ & $13 / 20 / 65$ & $0 / 20 / 0$ & $1 / 20 / 5$ & $12 / 20 / 60$ \\
Ankara & $1 / 20 / 5$ & $13 / 20 / 65$ & $0 / 20 / 0$ & $4 / 20 / 20$ & $14 / 20 / 70$ \\
Aydın & $0 / 20 / 0$ & $9 / 20 / 45$ & $0 / 20 / 0$ & $2 / 20 / 10$ & $10 / 20 / 50$ \\
Bartın & $1 / 20 / 5$ & $7 / 20 / 35$ & $0 / 20 / 0$ & $5 / 20 / 25$ & $12 / 20 / 60$ \\
Batman & $1 / 19 / 5.26$ & $15 / 19 / 78.95$ & $0 / 19 / 0$ & $9 / 19 / 47.37$ & $8 / 19 / 42.11$ \\
Çorum & $1 / 20 / 5$ & $9 / 20 / 45$ & $0 / 20 / 0$ & $2 / 20 / 10$ & $15 / 20 / 75$ \\
Elazı̆ & $0 / 20 / 0$ & $8 / 20 / 40$ & $0 / 20 / 0$ & $0 / 20 / 0$ & $14 / 20 / 70$ \\
Iğdır & $0 / 20 / 0$ & $1 / 20 / 5$ & $0 / 20 / 0$ & $2 / 20 / 10$ & $7 / 20 / 35$ \\
Isparta & $1 / 20 / 5$ & $13 / 20 / 65$ & $0 / 20 / 0$ & $2 / 20 / 10$ & $12 / 20 / 60$ \\
Karabük & $0 / 20 / 0$ & $5 / 20 / 25$ & $0 / 20 / 0$ & $3 / 20 / 15$ & $15 / 20 / 75$ \\
Kars & $0 / 20 / 0$ & $1 / 20 / 5$ & $0 / 20 / 0$ & $1 / 20 / 5$ & $10 / 20 / 50$ \\
Kirşehir & $2 / 20 / 10$ & $13 / 20 / 65$ & $0 / 20 / 0$ & $5 / 20 / 25$ & $11 / 20 / 55$ \\
Mardin & $0 / 20 / 0$ & $12 / 20 / 60$ & $0 / 20 / 0$ & $7 / 20 / 35$ & $14 / 20 / 70$ \\
Niğde & $1 / 20 / 5$ & $5 / 20 / 25$ & $0 / 20 / 0$ & $4 / 20 / 20$ & $17 / 20 / 85$ \\
Samsun & $0 / 20 / 0$ & $0 / 20 / 0$ & $0 / 20 / 0$ & $1 / 20 / 5$ & $0 / 20 / 0$ \\
Total & $8 / 299 / 2.68$ & $124 / 299 / 41.47$ & $0 / 299 / 0$ & $48 / 299 / 16.05$ & $171 / 299 / 57.19$ \\
\hline
\end{tabular}

$\mathrm{n}$ : number of positive samples, $\mathrm{N}$ : the total number of tested samples, \%: prevalence of infection.

\subsection{Phylogenetic Analysis}

In the present study, phylogenetic trees of B. ovis, T. ovis, A. ovis, and A. phagocytophilum were constructed based on BoSSUrRNA, ToSSUrRNA, MSP4, and 16S rRNA genes, respectively. The sequences of BoSSUrRNA obtained in the study (MT337501, MT337502) established a well-supported clade with the sequences from Turkey and other countries (Figure 1). These sequences revealed $99.10 \%-100 \%$ nucleotide sequence identity with the sequences previously reported from Iraq, Iran, Portugal, Spain, Tunisia, Uganda, and Turkey (99.77\%-100\%). Accordingly, ToSSUrRNA sequences (MT337516 and MT337516) fell into the same cluster with previous sequences from Turkey and other countries shown on the phylogenetic tree with nucleotide sequence identity value $100 \%$ (Figure 2). AoMSP4 sequences (MT344080, MT344081, and MT344082) also formed a well-supported clade with the sequences reported from some African, Asian, and European countries (Figure 3). The nucleotide sequence identity values of AoMSP4 sequences ranged from $99.71 \%$ to 100\%. Anaplasma phagocytophilum 16S rRNA sequences obtained in this study (MT337504, MT337505, MT337506, MT337507, MT337508) clustered together with previously reported sequences from China, Iraq, Italy, Tunisia, and Turkey with the nucleotide sequence identity values $98.17 \%-100 \%$ (Figure 4 ). The submitted two sequences of B. ovis (MT337501, MT337502) from this study showed $100 \%$ identity and similarity to each other. This situation was determined as 100\% for T. ovis sequences (MT337516, MT337516), 99\%-100\% for $A$. ovis sequences (MT344080-82), and $98 \%-100 \%$ for $A$. phagocytophilum sequences (MT337504-08).

\subsection{Statistical Analysis}

Considering the molecular prevalences of each pathogen in fifteen different provinces, statistical analysis was conducted to elucidate the statistical significance of the differences in molecular prevalence values. The present study established a statistically significant difference when the molecular prevalence values of $A$. ovis $\left(p=0.002, \chi^{2}=33.474\right)$, A. phagocytophilum $\left(p=0.001, \chi^{2}=49.105\right)$, and T. ovis $\left(p=0.001, \chi^{2}=73.199\right)$ in fifteen different provinces were examined. No statistically significant difference was observed for B. ovis $\left(p=0.680, \chi^{2}=11.082\right)$ and T. lestoquardi. The molecular prevalence of T. lestoquardi was the same in all provinces, and no positivity was determined in any city. Further information about statistical analysis is illustrated in Table 3. 
Table 2. Distribution of mixed infections in sheep blood samples.

\begin{tabular}{|c|c|c|c|c|c|c|c|c|c|c|c|c|c|c|c|}
\hline & \multicolumn{5}{|c|}{ Single Infections (n/\%) } & \multicolumn{5}{|c|}{ Dual Infections (n/\%) } & \multicolumn{3}{|c|}{ Triple Infections (n/\%) } & \multirow{2}{*}{$\begin{array}{c}\begin{array}{c}\text { Quadruple } \\
\text { Infections } \\
(\mathrm{n} / \%)\end{array} \\
B o+T o+ \\
A o+A p\end{array}$} & \multirow{2}{*}{$\begin{array}{l}\text { Total } \\
(\mathrm{n} / \%)\end{array}$} \\
\hline & Bo & To & $T l$ & Ao & $A p$ & $B o+T o$ & $B o+A p$ & $T o+A o$ & $T o+A p$ & $A o+A p$ & $B o+T o+A o$ & $B o+T o+A p$ & $T o+A o+A p$ & & \\
\hline Afyon & - & $4 / 20$ & - & - & $4 / 20$ & - & - & $1 / 5$ & $8 / 40$ & - & - & - & - & - & $17 / 85$ \\
\hline Ankara & - & $3 / 15$ & - & - & $4 / 20$ & - & $1 / 5$ & $1 / 5$ & $6 / 30$ & - & - & - & $3 / 15$ & - & $18 / 90$ \\
\hline Aydın & - & $2 / 10$ & - & - & $4 / 20$ & - & - & $1 / 5$ & $5 / 25$ & - & - & - & $1 / 5$ & - & $13 / 65$ \\
\hline Bartın & - & $1 / 5$ & - & $1 / 5$ & $5 / 25$ & - & - & - & $3 / 15$ & $1 / 5$ & - & - & $2 / 10$ & $1 / 5$ & $14 / 70$ \\
\hline Batman & - & $5 / 26.3$ & - & $3 / 15.8$ & $1 / 5.3$ & - & - & $3 / 15.8$ & $3 / 15.8$ & - & - & $1 / 5.3$ & $3 / 15.8$ & - & $19 / 100$ \\
\hline Elazı̆̆ & - & $2 / 10$ & - & - & $8 / 40$ & - & - & - & $6 / 30$ & - & - & - & - & - & $16 / 80$ \\
\hline Iğgır & - & - & - & $2 / 10$ & $6 / 30$ & - & - & - & $1 / 5$ & - & - & - & - & - & $9 / 45$ \\
\hline Isparta & - & $3 / 15$ & - & - & $4 / 20$ & - & - & $1 / 5$ & $8 / 40$ & - & $1 / 5$ & - & - & - & $17 / 85$ \\
\hline Karabük & - & $1 / 5$ & - & - & $10 / 50$ & - & - & - & $2 / 10$ & $1 / 5$ & - & - & $2 / 10$ & - & $16 / 80$ \\
\hline Kars & - & - & - & $1 / 5$ & $9 / 45$ & - & - & - & $1 / 5$ & - & - & - & - & - & $11 / 55$ \\
\hline Kırşehir & - & $2 / 10$ & - & $1 / 5$ & $2 / 10$ & - & - & $1 / 5$ & $7 / 35$ & - & $1 / 5$ & - & $1 / 5$ & $1 / 5$ & $16 / 80$ \\
\hline Mardin & - & $2 / 10$ & - & $1 / 5$ & $4 / 20$ & - & - & - & $4 / 20$ & - & - & - & $6 / 30$ & - & $17 / 85$ \\
\hline Niğde & - & - & - & - & $14 / 70$ & $1 / 5$ & - & - & - & - & - & - & $4 / 20$ & - & $19 / 95$ \\
\hline Samsun & - & - & - & $1 / 5$ & - & - & - & - & - & - & - & - & - & - & $1 / 5$ \\
\hline Total & $-/ 0$ & $25 / 8.36$ & $-/ 0$ & $10 / 3.34$ & $82 / 27.42$ & $1 / 0.33$ & $1 / 0.33$ & $9 / 3.01$ & $60 / 20.07$ & $2 / 0.67$ & $2 / 0.67$ & $2 / 0.67$ & $23 / 7.69$ & $2 / 0.67$ & $219 / 73.24$ \\
\hline
\end{tabular}

n: number of positive samples, \%: prevalence of infection, Bo: Babesia ovis, To: Theileria ovis, Tl: Theileria lestoquardi, Ao: Anaplasma ovis, Ap: Anaplasma phagocytophilum. 


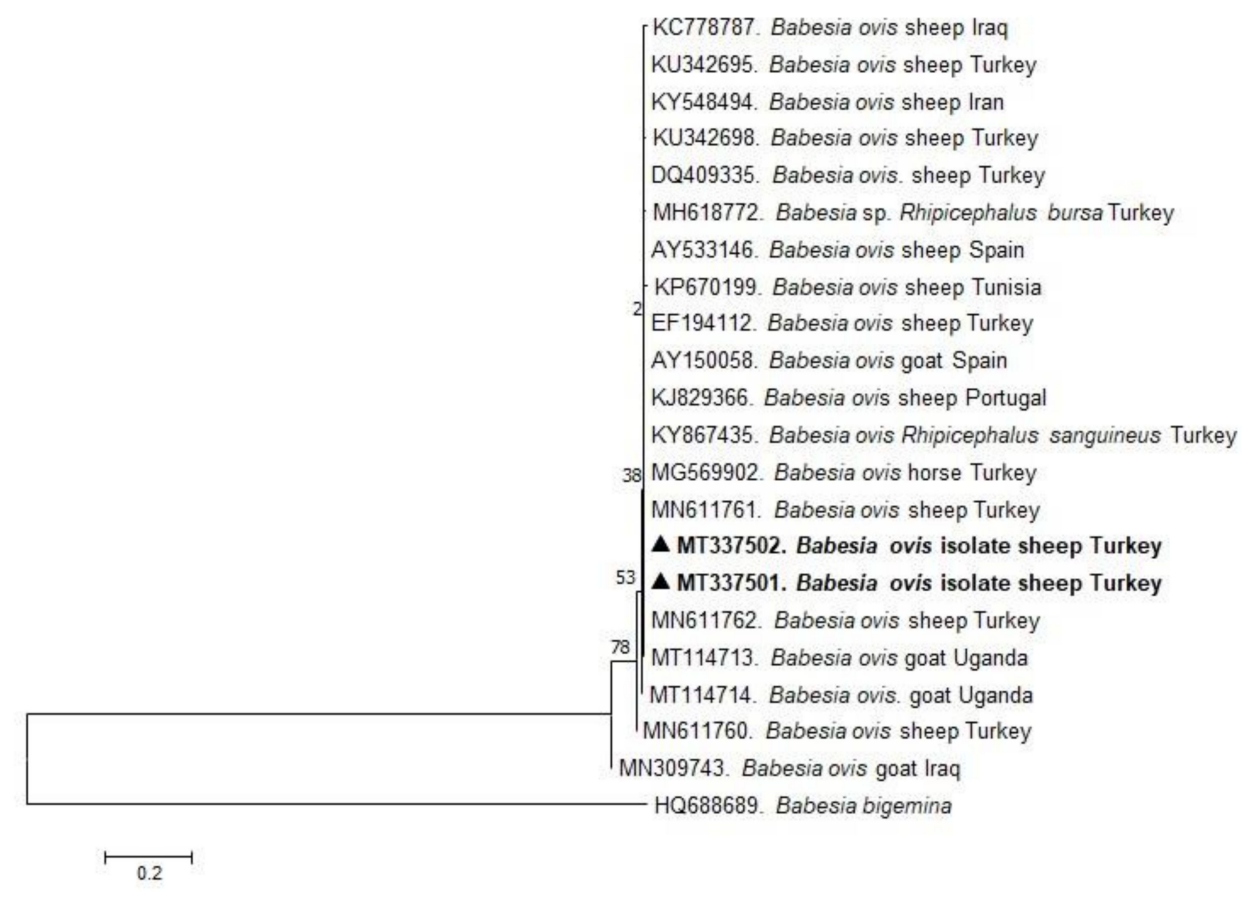

Figure 1. Phylogenetic analysis of the Maximum Likelihood method based on Babesia ovis BoSSU rRNA gene sequences. Numbers at nodes represent the percentage occurrence of clades in 1000 bootstrap replications of the data. Sequences from this study are shown in bold font. The 18S rRNA gene sequences of Babesia bigemina (HQ688689) are used as outgroup.

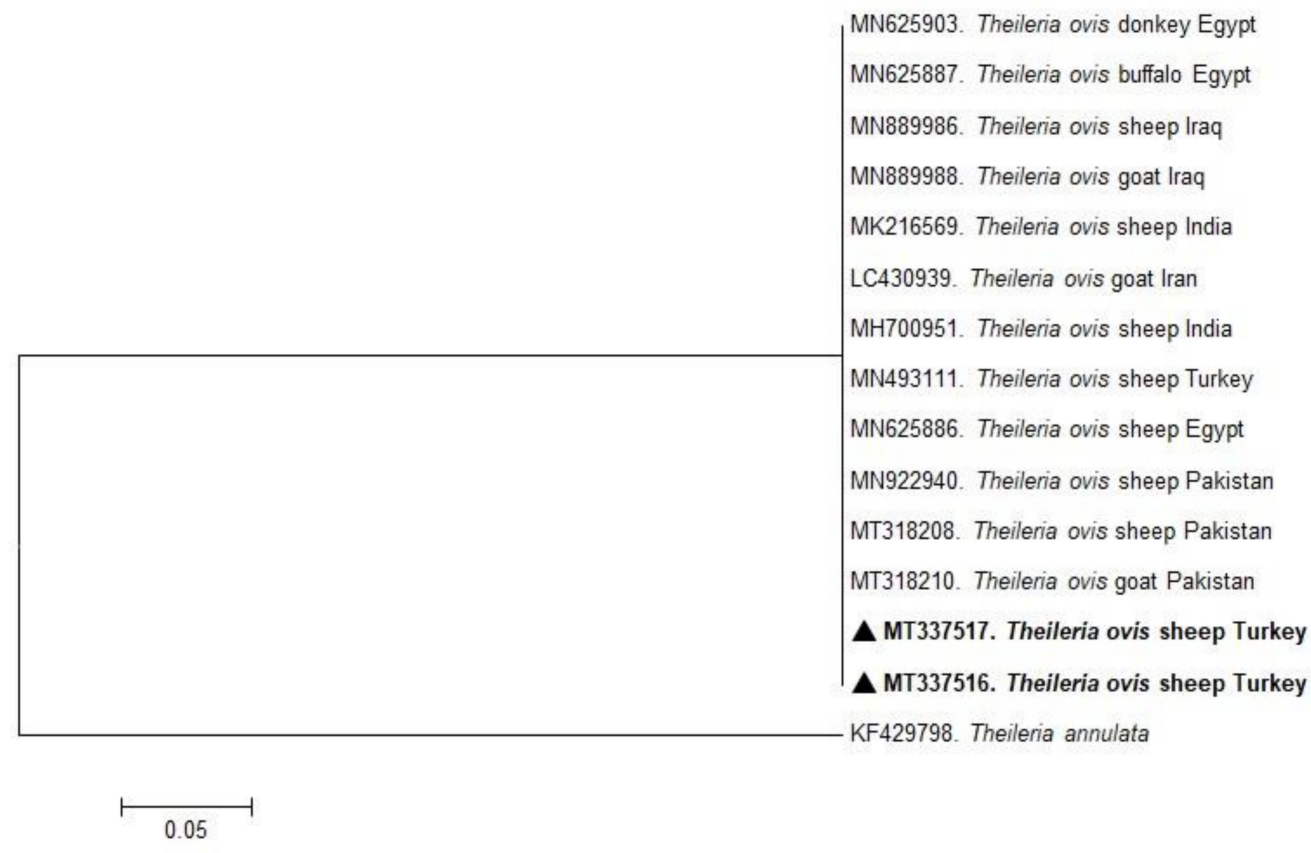

Figure 2. Phylogenetic analysis of the Maximum Likelihood method based on Theileria ovis ToSSU rRNA gene sequences. Numbers at nodes reflect the percentage occurrence of clades in 1000 bootstrap replications of the data. Sequences from this study are highlighted in bold font. The 18S rRNA gene sequences of Theileria annulata (KF429798) served as outgroup. 


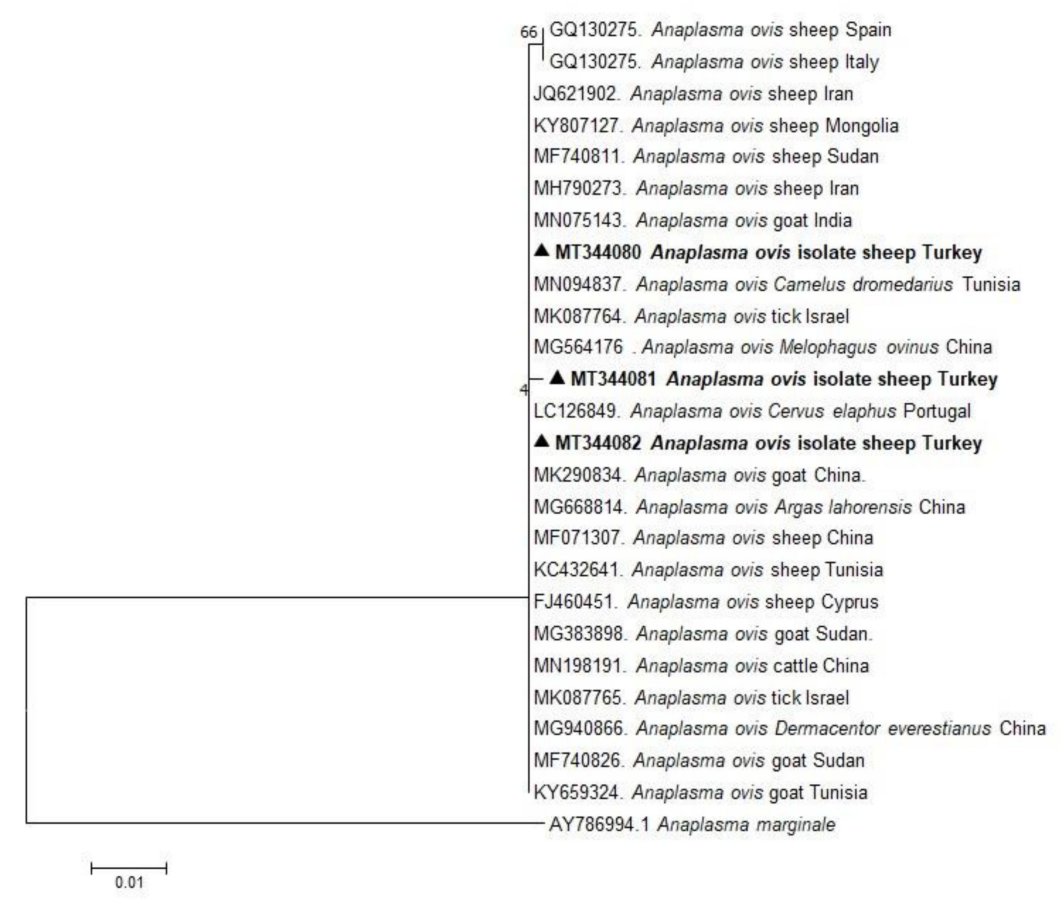

Figure 3. Phylogenetic analysis of the Maximum Likelihood method based on Anaplasma ovis MSP4 gene sequences. Numbers at nodes represent the percentage occurrence of clades in 1000 bootstrap replications of the data. Sequences from this study are given in bold font. The MSP4 gene sequences of Anaplasma marginale (AY786994) are used as outgroup.

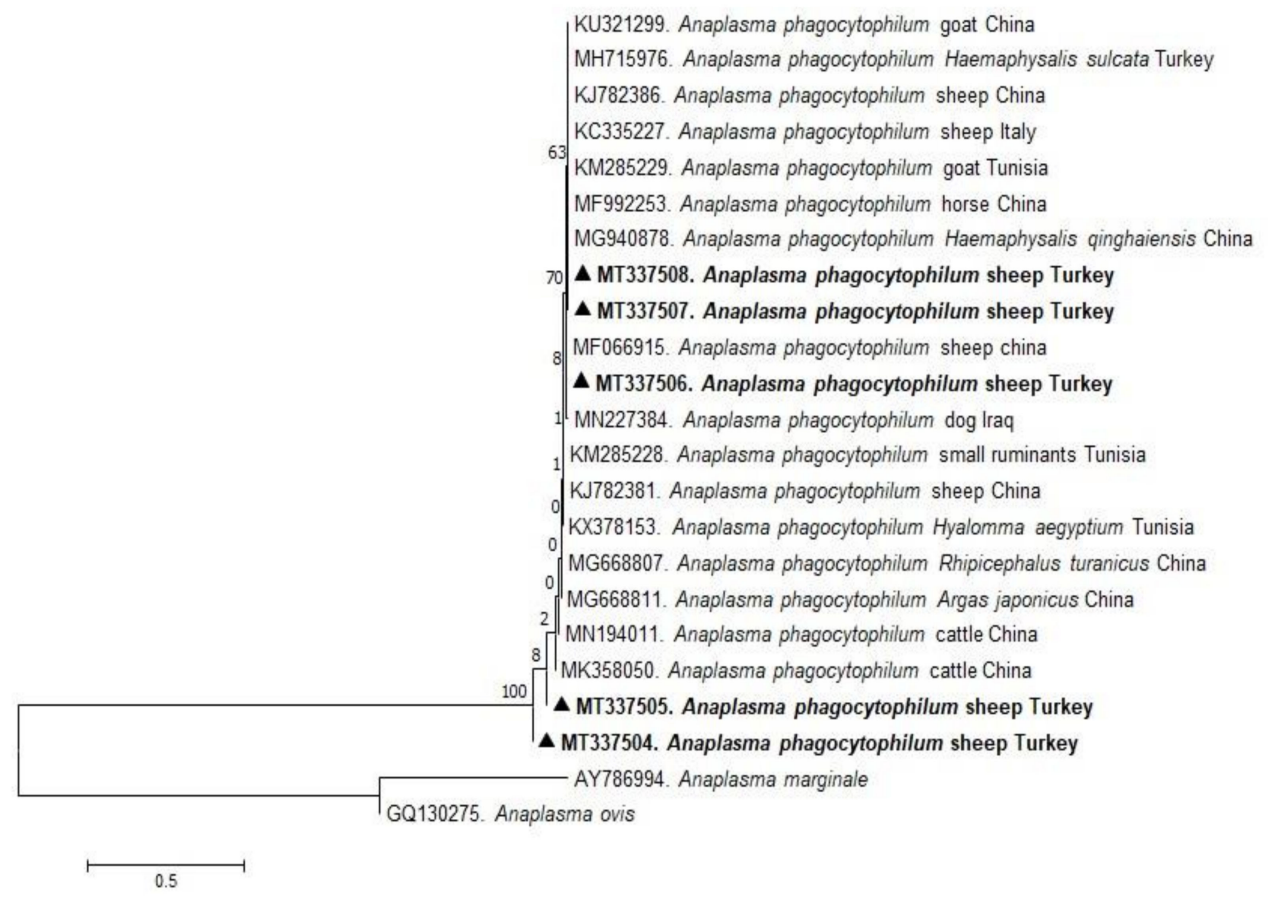

Figure 4. Phylogenetic analysis of the Maximum Likelihood method based on Anaplasma phagocytophilum 16S rRNA gene sequences. Numbers at nodes signify the percentage occurrence of clades in 1000 bootstrap replications of the data. Sequences from this study are written in bold font. The MSP4 gene sequences of Anaplasma phagocytophilum (AY786994) are used as outgroup. 
Table 3. Provincial comparison of molecular prevalences of tick-borne pathogens.

\begin{tabular}{|c|c|c|c|c|c|c|c|c|c|c|c|c|c|c|c|c|c|}
\hline & & Niğde & Iğdır & Aydın & Mardin & Bartın & Kars & Samsun & Afyon & Elazı̆g & Karabük & Çorum & Ankara & Isparta & Kırşehir & Batman & Total \\
\hline \multirow[b]{2}{*}{ A. ovis } & $\begin{array}{l}\mathrm{N} \\
\%\end{array}$ & $\begin{array}{l}16_{a, b, c, d} \\
80\end{array}$ & $\begin{array}{c}18_{\mathrm{b}, \mathrm{d}, \mathrm{e}} \\
90\end{array}$ & $\begin{array}{l}18_{\mathrm{b}, \mathrm{d}, \mathrm{e}} \\
90\end{array}$ & $\begin{array}{c}13_{c, d} \\
65\end{array}$ & $\begin{array}{c}15_{a, b, c, d} \\
75\end{array}$ & $\begin{array}{c}19_{\mathrm{b}, \mathrm{e}} \\
95\end{array}$ & $\begin{array}{c}19_{\mathrm{b}, \mathrm{e}} \\
95\end{array}$ & $\begin{array}{c}19_{\mathrm{b}, \mathrm{e}} \\
95\end{array}$ & $\begin{array}{l}20_{\mathrm{e}} \\
100\end{array}$ & $\begin{array}{c}17_{\mathrm{b}, \mathrm{d}, \mathrm{e}} \\
85\end{array}$ & $\begin{array}{c}18_{\mathrm{b}, \mathrm{d}, \mathrm{e}} \\
90\end{array}$ & $\begin{array}{l}16_{a, b, c, d} \\
80\end{array}$ & $\begin{array}{c}18_{\mathrm{b}, \mathrm{d}, \mathrm{e}} \\
90\end{array}$ & $\begin{array}{c}15_{\mathrm{a}, \mathrm{b}, \mathrm{c}, \mathrm{d}} \\
75\end{array}$ & $\begin{array}{l}10_{a, c} \\
52.6\end{array}$ & $\begin{array}{l}251 \\
83.9\end{array}$ \\
\hline & $\begin{array}{l}\mathrm{P} \\
\%\end{array}$ & $\begin{array}{l}4_{a, b, c, d} \\
20\end{array}$ & $\begin{array}{c}2 \mathrm{~b}, \mathrm{~d}, \mathrm{e} \\
10\end{array}$ & $\begin{array}{c}2 \mathrm{~b}, \mathrm{~d}, \mathrm{e} \\
10\end{array}$ & $\begin{array}{c}7_{c, d} \\
35\end{array}$ & $\begin{array}{c}5_{a, b, c, d} \\
25\end{array}$ & $1_{\mathrm{b}, \mathrm{e}}$ & $1_{\mathrm{b}, \mathrm{e}}$ & $\begin{array}{c}1_{\mathrm{b}, \mathrm{e}} \\
5\end{array}$ & $\begin{array}{c}0_{\mathrm{e}} \\
0\end{array}$ & $3_{\mathrm{b}, \mathrm{d}, \mathrm{e}}$ & $\begin{array}{c}2 \mathrm{~b}, \mathrm{~d}, \mathrm{e} \\
10\end{array}$ & $\begin{array}{l}4_{a, b, c, d} \\
20\end{array}$ & $\begin{array}{c}2 \mathrm{~b}, \mathrm{~d}, \mathrm{e} \\
10\end{array}$ & $\begin{array}{c}5_{\mathrm{a}, \mathrm{b}, \mathrm{c}, \mathrm{d}} \\
25\end{array}$ & $\begin{array}{r}9 \mathrm{a}, \mathrm{c} \\
47.4\end{array}$ & $\begin{array}{c}48 \\
16.1\end{array}$ \\
\hline \multirow{4}{*}{$\begin{array}{c}\text { A. } \\
\text { phagocytophilum }\end{array}$} & $\mathrm{N}$ & $3 a$ & $13_{\mathrm{b}}$ & $10_{\mathrm{b}, \mathrm{c}, \mathrm{d}}$ & $6_{a, c, d}$ & $8_{a, b, c, d}$ & $10_{\mathrm{b}, \mathrm{c}, \mathrm{d}}$ & $20_{\mathrm{e}}$ & $8_{a, b, c, d}$ & $6_{a, c, d}$ & $5_{\mathrm{a}, \mathrm{d}}$ & $5_{a, d}$ & $6_{\mathrm{a}, \mathrm{c}, \mathrm{d}}$ & $8_{a, b, c, d}$ & $9_{\mathrm{b}, \mathrm{c}, \mathrm{d}}$ & $11_{b, c}$ & 128 \\
\hline & $\%$ & 15 & 65 & 50 & 30 & 40 & 50 & 100 & 40 & 30 & 25 & 25 & 30 & 40 & 45 & 57.9 & 42.8 \\
\hline & $\mathrm{P}$ & $17 \mathrm{a}$ & $7_{\mathrm{b}}$ & $10_{\mathrm{b}, \mathrm{c}, \mathrm{d}}$ & $14_{\mathrm{a}, \mathrm{c}, \mathrm{d}}$ & $12_{a, b, c, d}$ & $10_{b, c, d}$ & $0_{\mathrm{e}}$ & $12_{a, b, c, d}$ & $14_{\mathrm{a}, \mathrm{c}, \mathrm{d}}$ & $15_{\mathrm{a}, \mathrm{d}}$ & $15_{\mathrm{a}, \mathrm{d}}$ & $14_{\mathrm{a}, \mathrm{c}, \mathrm{d}}$ & $12_{a, b, c, d}$ & $11_{\mathrm{b}, \mathrm{c}, \mathrm{d}}$ & $8_{\mathrm{b}, \mathrm{c}}$ & 171 \\
\hline & $\%$ & 85 & 35 & 50 & 70 & 60 & 50 & 0 & 60 & 70 & 75 & 75 & 70 & 60 & 55 & 42.1 & 57.2 \\
\hline \multirow{4}{*}{ B. ovis } & $\mathrm{N}$ & $19 \mathrm{a}$ & $20_{a}$ & $20 a$ & $20 a$ & $19 \mathrm{a}$ & $20_{a}$ & $20_{a}$ & $20 \mathrm{a}$ & $20 \mathrm{a}$ & $20_{a}$ & $19 a$ & $19 \mathrm{a}$ & $19 a$ & $18 \mathrm{a}$ & $18 \mathrm{a}$ & 291 \\
\hline & $\%$ & 95 & 100 & 100 & 100 & 95 & 100 & 100 & 100 & 100 & 100 & 95 & 95 & 95 & 90 & 94.7 & 97.3 \\
\hline & $\mathrm{P}$ & $1_{\mathrm{a}}$ & $0_{a}$ & $0_{a}$ & $0_{a}$ & $1_{\mathrm{a}}$ & $0_{a}$ & $0_{a}$ & $0_{a}$ & $0_{a}$ & $0_{a}$ & $1_{a}$ & $1_{\mathrm{a}}$ & $1_{\mathrm{a}}$ & $2 \mathrm{a}$ & $1_{\mathrm{a}}$ & 8 \\
\hline & $\%$ & 5 & 0 & 0 & 0 & 5 & 0 & 0 & 0 & 0 & 0 & 5 & 5 & 5 & 10 & 5.3 & 2.7 \\
\hline \multirow{4}{*}{ T. ovis } & $\mathrm{N}$ & $15_{a, b, c, d, e, f, g}$ & $19_{\mathrm{f}, \mathrm{g}, \mathrm{h}}$ & $11_{\mathrm{d}, \mathrm{e}, \mathrm{i}, \mathrm{i}, \mathrm{k}, \mathrm{k}}$ & $8_{\mathrm{k}, \mathrm{l}, \mathrm{m}}$ & $13_{c, e, i, j, k, k}$ & $19_{b, g, h}$ & $20_{\mathrm{h}}$ & $7_{\mathrm{j}, \mathrm{l}, \mathrm{m}}$ & $12_{a, c, d, e, i, j, k, l}$ & $15_{a, b, c, d, e, f, g}$ & 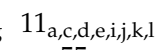 & $7_{\mathrm{i}, \mathrm{j}, \mathrm{k}, \mathrm{l}, \mathrm{l}, \mathrm{m}}$ & $7_{\mathrm{i}, \mathrm{j}, \mathrm{k}, \mathrm{l}, \mathrm{m}}$ & $7_{\mathrm{i}, \mathrm{j}, \mathrm{k}, \mathrm{l}, \mathrm{m}}$ & $4_{m}$ & 175 \\
\hline & $\%$ & 75 & 95 & 55 & 40 & 65 & 95 & 100 & 35 & 60 & 75 & 55 & 35 & 35 & 35 & 21.1 & 58.5 \\
\hline & $\mathrm{P}$ & 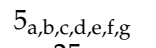 & $1_{\mathrm{f}, \mathrm{g}, \mathrm{h}}$ & $9_{\mathrm{d}, \mathrm{e}, \mathrm{i}, \mathrm{j}, \mathrm{k}, \mathrm{l}}$ & $12_{\mathrm{k}, \mathrm{l}, \mathrm{m}}$ & $7_{c, e, i, j, k, 1}$ & $1_{\mathrm{b}, \mathrm{g}, \mathrm{h}}$ & $0_{\mathrm{h}}$ & $13_{\mathrm{j}, \mathrm{l}, \mathrm{m}}$ & $8_{\mathrm{a}, \mathrm{c}, \mathrm{d}, \mathrm{e}, \mathrm{i}, \mathrm{j}, \mathrm{k}, \mathrm{l}}$ & $5_{a, b, c, d, e, f, g}$ & 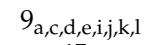 & $13_{\mathrm{i}, \mathrm{j}, \mathrm{k}, \mathrm{l}, \mathrm{m}}$ & $13_{\mathrm{i}, \mathrm{j}, \mathrm{k}, \mathrm{l}, \mathrm{m}}$ & $13_{\mathrm{i}, \mathrm{j}, \mathrm{k}, \mathrm{l}, \mathrm{m}}$ & $15_{m}$ & 124 \\
\hline & $\%$ & 25 & 5 & 45 & 60 & 35 & 5 & 0 & 65 & 40 & 25 & 45 & 65 & 65 & 65 & 78.9 & 41.5 \\
\hline \multirow{3}{*}{ T. lestoquardi } & $\mathrm{N}$ & $20 \mathrm{a}$ & $20_{a}$ & $20_{a}$ & $20 \mathrm{a}$ & $20 a$ & $20_{a}$ & $20_{a}$ & $20 \mathrm{a}$ & $20_{a}$ & $20_{a}$ & $20 \mathrm{a}$ & $20 \mathrm{a}$ & $20 \mathrm{a}$ & $20_{a}$ & $19 \mathrm{a}$ & 299 \\
\hline & $\%$ & 100 & 100 & 100 & 100 & 100 & 100 & 100 & 100 & 100 & 100 & 100 & 100 & 100 & 100 & 100 & 100 \\
\hline & $\mathrm{P}$ & $0_{a}$ & $0_{a}$ & $0_{a}$ & $0_{a}$ & $0_{a}$ & $0_{a}$ & $0_{\mathrm{a}}$ & $0_{\mathrm{a}}$ & $0_{\mathrm{a}}$ & $0_{\mathrm{a}}$ & $0_{\mathrm{a}}$ & $0_{\mathrm{a}}$ & $0_{a}$ & $0_{\mathrm{a}}$ & $0_{\mathrm{a}}$ & $0_{\mathrm{a}}$ \\
\hline
\end{tabular}

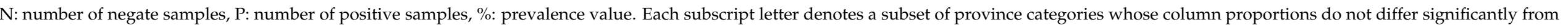
each other. 


\section{Discussion}

Ticks play an important role in veterinary and human medicine owing to their ability to transmit some infectious pathogens, including bacteria, helminths, protozoa, and viruses. It is considered that ticks are the major disease-causing pathogens in wild and domestic animals [25]. In the present study, we screened ovine tick-borne hemoprotozoan and rickettsial agents in sheep from fifteen different provinces located in six geographical regions of Turkey, and B. ovis, T. ovis, A. ovis, and A. phagocytophilum were identified in blood samples. However, T. lestoquardi was not detected in any of the samples.

Although bovine piroplasmosis attracted great attention in the past years, interest in ovine piroplasmosis attributed to its socio-economic impacts has recently increased [26]. Babesiosis is one of the most significant infections caused by piroplasms and several pathogenic and non-pathogenic Babesia species (B. crassa, B. foliata, B. motasi, B. ovis, B. taylori, Babesia sp. (China), and Babesia sp. (Xinjiang)) are responsible for ovine babesiosis in small ruminants [27-29]. Babesia ovis is the most pathogenic species affecting sheep among these species [9] and ovine babesiosis caused by this hemoprotozoan parasite has a country-wide endemic instability in Turkey [30]. It was reported that the seroprevalence of B. ovis varied from $35.0 \%$ to $74.4 \%$ [31]. Although Sevinc et al. [23] estimated an infection rate of $70.81 \%$ by molecular techniques in sheep with clinical signs, other molecular studies revealed the infection rate ranging from $0 \%$ to $21.42 \%$ in randomly selected apparently healthy sheep from different regions and provinces of Turkey [14,22,31-34]. With some considerable results, the data obtained in this study were in agreement with the outcomes documented in previous studies. Although several serological methods such as Indirect Fluorescent Antibody (IFA) test and recombinant $B$. ovis secreted antigen 1 based Enzyme-Linked Immunosorbent Assay (rBoSA1-ELISA) detected anti-B. ovis antibodies in all these provinces [30], molecular detection of $B$. ovis was only reported from Niğde province $[14,34]$. Present study elucidated B. ovis by molecular techniques in sheep for the first time in Ankara, Bartın, Batman, Çorum, Isparta, and Kırşehir provinces of Turkey. As a result of the literature search, no published paper was found. The obtained data can, thus, aid in implementing the envisaged control programs against ovine babesiosis in these provinces in the future.

Theileria parasites, transstadially transmitted by ixodid ticks, are the main pathogens of theileriosis in domestic and wild animals [35]. Small ruminants are adversely affected by Theileria species resulting in economic losses owing to the infections caused by these hemoprotozoan parasites [36]. Among the Theileria species infecting small ruminants, T. lestoquardi, T. luwenshuni, and T. uilenbergi are referred to as the agents of malignant theileriosis, whereas three other species, T. ovis, T. recondita, and T. seperata, are known as non-pathogenic or benign Theileria species [35]. Among Theileria species, T. ovis [37], T. luwenshuni, T. uilenbergi [14], and some Theileria isolates such as Theileria sp. MK [21], Theileria sp. OT1, and Theileria sp. OT3 [14] were detected in Turkey. PCR-based molecular studies reveal that the infection rate of T. ovis ranges from $17.0 \%$ to $61.4 \%$ in different parts of Turkey [31]. However, T. lestoquardi, the causative agent of malignant theileriosis, has not yet been obtained in Turkey [14]. In the present study, these pathogenic species were also not detected in any of the blood samples, consistent with the previous studies. The molecular prevalence of T. ovis (41.47\%) was found to be in accordance with the prevalences determined in the previous studies. Except for Samsun province, located in the Black Sea Region, T. ovis was detected in all the other provinces and has been determined to be widely distributed throughout Turkey. Normally, T. ovis causes mild infections and, therefore, has less economic significance. However, the hemoprotozoan parasites commonly detected in the present study should not be ignored because severe disease cases can occur under stressful conditions [38].

Several Anaplasma species, including A. ovis, A. marginale, and the human granulocytic anaplasmosis (HGA) agent $A$. phagocytophilum cause ovine anaplasmosis [10]. Anaplasma ovis normally results in mild clinical signs, and A. phagocytophilum unfavorably affect the livestock economy leading to various clinical signs with a sudden drop in milk 
production, abortions, fertility problems, and reduced weight gain especially depending on the stress factors such as animal movement, excessive tick infestation, heat, deworming, coinfection, vaccination, and long-distance transportation [3,4,19,36,39]. Despite these crucial impacts, ovine anaplasmosis is still neglected among TBDs [40]. Molecular investigations of ovine anaplasmosis caused by $A$. ovis have been maintained for decades; however, there are a limited number of studies regarding $A$. ovis infections in Turkey [14,22,23,41-43]. Comparing the molecular investigations in Turkey, the prevalence of $A$. ovis infection $(16.05 \%)$ obtained in this study was found parallel to the prevalence values determined in Southern Turkey (15.9-21.8\%) [42], Central Anatolia (14.9\%), and South-East Anatolia regions (10.6\%) [39]. However, it was found lower than the prevalences determined in East Anatolia (67.35\%) [41], Thrace (58.8\%) [44], and Central Anatolia regions (56.94\%, $64.7 \%)[22,23]$ and a study covering a large part of Turkey (63.3\%) [14]. Except for Elaziğ province, A. ovis was detected in fourteen provinces in six of the seven geographical regions of Turkey in this study. The findings concluded by this and other studies validate that ovine $A$. ovis infection is endemic in Turkey. Being one of the human infectious agents, more attention should be given to $A$. ovis because of the widespread distribution in Turkey [16,17]. Renneker et al. [39] reported that $A$. ovis should no longer be ignored, and further studies are essential due to its zoonotic potential and economic impacts on small ruminant breeding.

The first investigation of $A$. phagocytophilum in sheep was conducted in Turkey in 2005, and the presence of antibodies formed against this rickettsial microorganism was detected [45]. It has been determined that the molecular prevalence of A. phagocytophilum in randomly selected sheep varied between $0 \%$ and $18.90 \%$ for fifteen years $[14,22,23,41,44,46]$; however, Benedicto et al. [43] detected A. phagocytophilum DNA in 62.5\% of the tick-infested sheep with clinical symptoms in a currently conducted study in Turkey. The prevalence of A. phagocytophilum estimated in this study is higher than the previously reported ones but lower than the current report of Benedicto et al. [43]. Considering that the study was carried out in randomly selected sheep, the infection rate of $A$. phagocytophilum is the highest rate detected in sheep in Turkey, and A. phagocytophilum was detected in all provinces except for one province (Samsun). This situation indicates that zoonotic A. phagocytophilum has a large-scale circulation among sheep and vector ticks and poses a significant infection risk for human beings. Ixodes ricinus, the primary vector of A. phagocytophilum in Europe, Haemaphysalis sulcata, and Rhipicephalus bursa were reported to carry this pathogen in Turkey [47-49]. Vector competency of the other tick species should be investigated, accounting for the high infection rate of $A$. phagocytophilum in sheep in Turkey.

The co-infection phenomenon of sheep attributed to the ovine piroplasms and Anaplasma species has been rarely investigated in Turkey. The causative agents of co-infections of small ruminants have been detected by using molecular techniques in different countries such as Iraq [13], Italy [50], Tunisia [51], Turkey [14,22,23], and South Africa [24]. Overall, $219(73.24 \%)$ of the surveyed sheep blood samples were tested positive for at least one pathogen in this study. The co-infection rate was determined as $46.58 \%$ (n: 102) among these infections. Dual, triple, and quadruple co-infection rates were detected as $71.57 \%$, $26.47 \%$, and $1.96 \%$, respectively. These different types of co-infections may adversely affect the prognosis of the TBDs, especially in stressful conditions in comparison to the animals infected with single species [22,23]. Sevinc et al. [23] highlighted a negative interaction between the coexistence of B. ovis and T. ovis in sheep. Further studies are necessary to explore new interactions, to get information regarding clinical effects, and to specify the best option of therapeutic applications in sheep co-infected with piroplasms and Anaplasma species.

In conclusion, we demonstrated the presence of B. ovis, T. ovis, A. ovis, and A. phagocytophilum in sheep in fifteen provinces belonging to six of the seven geographical regions of Turkey. Moreover, this study includes some information regarding rarely studied coinfections resulting from ovine tick-borne agents. Dual, triple, and quadruple co-infections were commonly identified in the study. Anaplasma ovis and A. phagocytophilum, which are of 
zoonotic importance, were detected as widespread throughout Turkey. The current study will contribute to the data regarding the molecular epidemiology of TBDs in Turkey and the envisaged control strategies of these diseases in the near future.

\section{Materials and Methods}

\subsection{Study Areas and Sample Collection}

Whole blood samples (n: 299) of sheep were collected from 15 provinces, including Afyon, Ankara, Aydın, Bartın, Batman, Çorum, Elazı̆̆, Iğdır, Isparta, Karabük, Kars, Kırşehir, Mardin, Niğde, and Samsun located in Aegean (Afyon, Aydın), Black Sea (Bartın, Karabük, Samsun), Central Anatolia (Ankara, Çorum, Kırşehir, Niğde), Eastern Anatolia (Elazığ, Iğdır, Kars), Mediterranean (Isparta), and Southeastern Anatolia (Batman, Mardin) regions of Turkey, between May and August of 2019 (Figure 5). Twenty blood samples were obtained from each city except for Batman (n: 19). The samples were collected from randomly selected apparently healthy sheep raised in small-type farms during the tick activity season. The owners of the sheep were informed about the study and their approval for sampling was received. They stated that the sampled sheep did not receive any ectocid treatment. All sheep were inspected in terms of tick infestation, but no tick infestation was detected in animals.

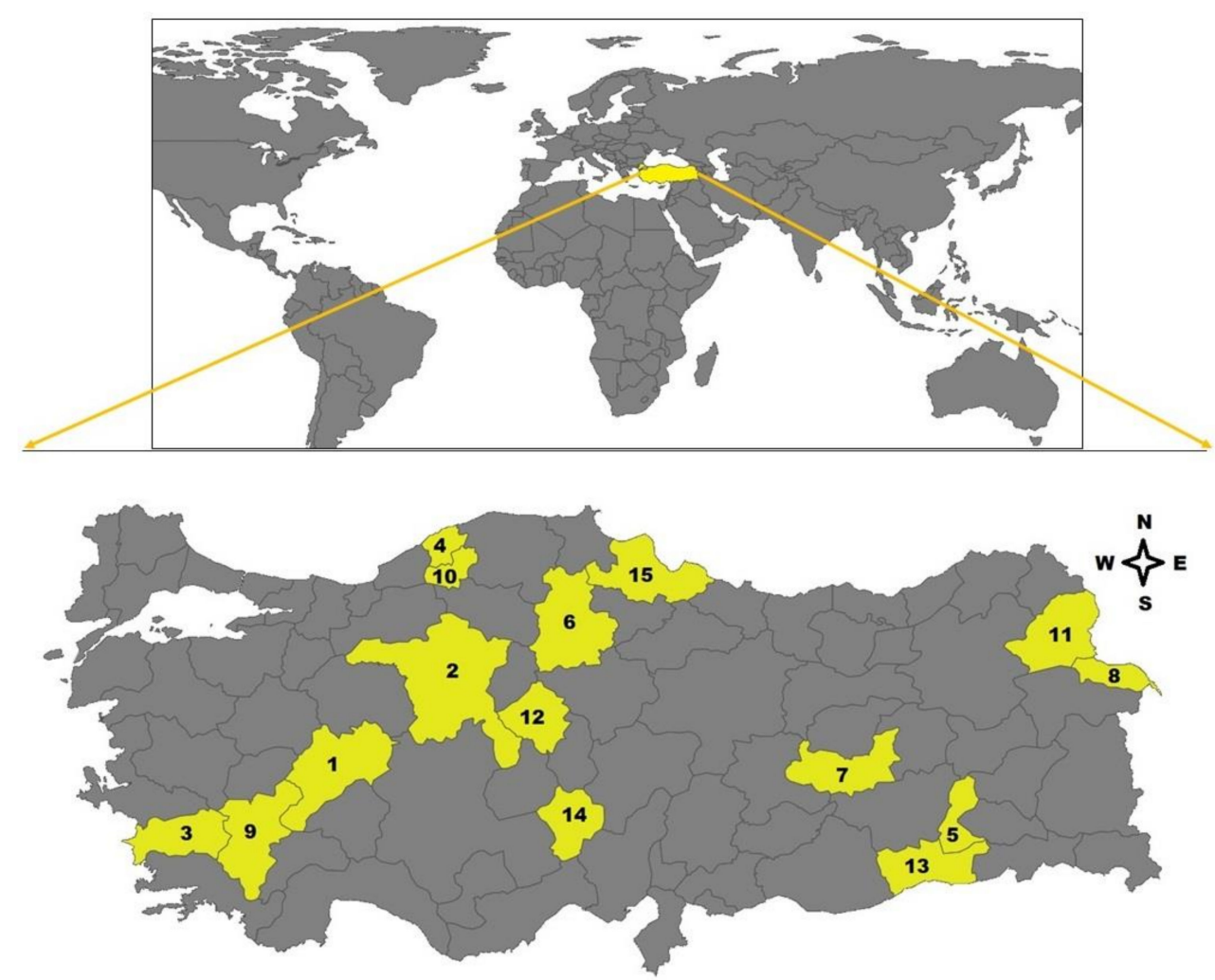

Figure 5. Map of Turkey highlighting fifteen provinces located in the six different geographical regions where the blood samples were collected (1. Afyon, 2. Ankara, 3. Aydın, 4. Bartın, 5. Batman, 6. Çorum, 7. Elazı̆̆, 8. Iğdır, 9. Isparta, 10. Karabük, 11. Kars, 12. Kırşehir, 13. Mardin, 14. Niğde, 15. Samsun).

\subsection{DNA Extraction}

The sheep were individually bled through the jugular vein, and $8 \mathrm{~mL}$ blood sample was collected into a tube containing ethylenediamine tetraacetic acid (EDTA) for each animal. Genomic DNA was extracted from the blood samples by using QIAamp ${ }^{\circledR}$ DNA Blood Mini Kit (QIAGEN, Hilden, Germany), following the manufacturer's instructions. The extracted genomic DNA was stored at $-20{ }^{\circ} \mathrm{C}$ until the molecular analysis. 


\subsection{Molecular Detection of Tick-Borne Pathogens}

Babesia ovis, T. ovis, T. lestoquardi, A. ovis, and A. phagocytophilum was investigated by species-specific PCR in each DNA sample. The screening was based on the procedures previously described by researchers, respectively listed in Table 4 with their thermocycling conditions. The target genes of species-specific PCR assays were B. ovis BoSSU rRNA, T. ovis ToSSU rRNA, T. lestoquardi 18S rRNA, A. ovis MSP4, and A. phagocytophilum $16 \mathrm{~S}$ rRNA as detailed in Table 4 . The reaction mixture had a final volume of $10 \mu \mathrm{L}$ containing $1 \mu \mathrm{L}$ of $10 \mathrm{X}$ ThermoPol Taq Reaction buffer, $0.2 \mu \mathrm{L}$ of dNTP mix, $0.2 \mu \mathrm{M}$ of each primer, $0.05 \mu \mathrm{L}$ Taq DNA polymerase (New England BioLabs, USA), $1.5 \mu \mathrm{L}$ of DNA template, and $6.85 \mu \mathrm{L}$ of double-distilled water. Positive controls were set as previously sequence-confirmed DNA templates, and double-distilled water served as negative controls.

Table 4. Primer pairs used in the standard and nPCR assays for detection of each pathogen.

\begin{tabular}{|c|c|c|c|c|c|c|}
\hline Species & $\begin{array}{l}\text { Target } \\
\text { Gene }\end{array}$ & Primer Name & Primer Sequence $\left(5^{\prime} \ldots\right.$ ' 3$)$ & $\begin{array}{l}\text { Expected Size } \\
\quad(\mathrm{bp})\end{array}$ & $\begin{array}{l}\text { Annealing } \\
\text { Temperature } \\
\quad\left({ }^{\circ} \mathrm{C}\right)\end{array}$ & References \\
\hline B. ovis & SSU rRNA & $\begin{array}{l}\text { Bov F } \\
\text { Bov R }\end{array}$ & $\begin{array}{l}\text { TGGGCAGGACCTTGGTTCTTCT } \\
\text { CCGCGTAGCGCCGGCTAAATA }\end{array}$ & 549 bp & 62 & $\begin{array}{c}\text { Aktas et al. } \\
\text { [32] }\end{array}$ \\
\hline T. ovis & SSU rRNA & $\begin{array}{l}\text { TSsr } 170-\mathrm{F} \\
\text { TSsr } 670-\mathrm{R}\end{array}$ & $\begin{array}{c}\text { TCGAGACCTTCGGGT } \\
\text { TCCGGACATTGTAAAACAAA }\end{array}$ & $520 \mathrm{bp}$ & 60 & $\begin{array}{l}\text { Aktas et al. } \\
\text { [52] }\end{array}$ \\
\hline T. lestoquardi & 18S rRNA & $\begin{array}{l}\text { T. lestoquardi } \mathrm{F} \\
\text { T. lestoquardi } \mathrm{R}\end{array}$ & $\begin{array}{c}\text { GTGCCGCAAGTGAGTCA } \\
\text { GGACTGATGAGAAGACGATGAG }\end{array}$ & $730 \mathrm{bp}$ & 52 & $\begin{array}{c}\text { Kirvar et al. } \\
\text { [53] }\end{array}$ \\
\hline A. ovis & $M S P-4$ & $\begin{array}{l}\text { MSP-4-F } \\
\text { MSP-4R }\end{array}$ & $\begin{array}{l}\text { TGAAGGGAGCGGGGTCATGGG } \\
\text { GAGTAATTGCAGCCAGGCACTCT }\end{array}$ & $347 \mathrm{bp}$ & 62 & Torina et al. \\
\hline $\begin{array}{l}\text { A. phagocy- } \\
\text { tophilum }\end{array}$ & 16S rRNA & $\begin{array}{c}\text { EE1 } \\
\text { EE2 } \\
\text { SSAp-F } \\
\text { SSAp-R }\end{array}$ & $\begin{array}{c}\text { TCCTGGCTCAGAACGAACGCTGGCGGC } \\
\text { AGTCACTGACCCAACCTTAAATGGCTG } \\
\text { GCT GAA TGT GGG GAT AAT TTA T } \\
\text { ATG GCT GCT TCC TTT CGG TTA }\end{array}$ & $1433 \mathrm{bp}$ & 55 & $\begin{array}{l}\text { Barlough } \\
\text { et al. [55] } \\
\text { Kawahara } \\
\text { et al. [56] }\end{array}$ \\
\hline
\end{tabular}

\subsection{Cloning}

Following PCR assays, B. ovis, T. ovis, A. ovis, and A. phagocytophilum amplicons were selected for sequencing. Agarose gel elution was employed to purify amplified PCR products using QIAquick Gel Extraction Kit (Qiagen, Germany), and eluted DNA concentrations were measured on a NanoDrop 2000 spectrophotometer. The extracts were then cloned into a pGEM vector according to the commercial protocol of $\mathrm{pGEM}^{\circledR}$-T Easy Vector System (Promega, USA). The template $(6 \mu \mathrm{L})$ was ligated into pGEM-T easy vector $(2 \mu \mathrm{L})$ using T4 DNA ligase and restriction buffer. Thereafter, the mixture was incubated at $16{ }^{\circ} \mathrm{C}$ for $2.5-3 \mathrm{~h}$ and kept at $4{ }^{\circ} \mathrm{C}$ overnight. Plasmid was transformed into Escherichia coli DH5 $\alpha$ competent cells. LB broth was added to every tube and incubated at $37^{\circ} \mathrm{C}$ in a shaker incubator for at least $1 \mathrm{~h}$. Meanwhile, LB agar plates were warmed up at $37^{\circ} \mathrm{C}$. After centrifugation ( $2500 \mathrm{rpm}$ for $3 \mathrm{~min}$ ) and removal of the supernatant, the remaining mixture was spread on LB agar plates using a spreader, followed by incubation at $37^{\circ} \mathrm{C}$ overnight. Recombinant clones from this transformation were then selected to be sequenced, transferred in LB broth with ampicillin $(50 \mu \mathrm{g} / \mathrm{mL})$ (Wako, Saitama, Japan), and incubated at $37^{\circ} \mathrm{C}$ overnight in a shaker incubator. The plasmid was extracted from this culture using the Nucleospin ${ }^{\circledR}$ Plasmid QuickPure (Macherey-Nagel-German) Kit.

\subsection{Sequence Analysis}

After cloning, sequence analysis was performed with the help of the Big Dye Terminator Cycle Sequencing Kit (Applied Biosystems, Waltham, MA, USA) using an ABI PRISM 3100 Genetic Analyzer (Applied Biosystems, Waltham, MA, USA). Sequences obtained in the present study were deposited to the GenBank database of the National Center for Biotechnology Information using BankIt. The GenBank accession numbers were assigned as follows: MT337501, MT337502 for B. ovis; MT337516, MT337517 for T. ovis; MT344080, MT344081, and MT344082 for A. ovis; and MT337504, MT337505, MT337506, MT337507, and MT337508 for A. phagocytophilum. 


\subsection{Phylogenetic Analysis}

Nucleotide sequence similarities and identities were determined by using BLASTn analysis. The Neighbor-joining and Maximum likelihood methods of the MEGA version 7 software were employed to construct phylogenetic trees. Bootstrap analysis with 1000 replication was used to estimate the confidence of the nodes and branches of the trees.

\subsection{Ethical Statement}

The owners of the sheep were informed about the study, and their approval was obtained for sampling. All experimental procedures were carried out according to the ethical guidelines for the use of animal samples permitted by Obihiro University of Agriculture and Veterinary Medicine (Approval ID: 18-41).

\subsection{Statistical Analysis}

A cross-tabulation evaluation was made using categorical data, numbers, and percentages. In cases where the expected cells fell below $20 \%$, the data were determined using the Monte Carlo Simulation Method for inclusion in the analysis. The significance level was indicated to be $\alpha=0.05$. The SPSS 25 (IBM Corp. Released 2017. IBM SPSS Statistics for Windows, Version 25.0. Armonk, NY: IBM Corp.) statistical package program was adopted to analyze the data. $p$-Values were computed to determine the level of statistical significance between provinces according to the obtained data.

Author Contributions: Conceptualization, O.C., B.B., T.M., X.X., and F.S.; methodology, O.C., B.B., C.C., E.M.G., and M.L.; investigation, O.C., and B.B.; data curation, O.C., B.B., and F.S.; writing —original draft preparation, O.C., and B.B.; writing-review and editing, O.C., B.B., C.C., E.M.G., M.L., T.M., X.X., and F.S.; project administration, T.M. and X.X.; funding acquisition, T.M. and X.X. All authors have read and agreed to the published version of the manuscript.

Funding: The Japanese Society for the Promotion of Science (JSPS) Core-to-Core Program and Grantin-Aid for Scientific Research (18KK0188) from the Ministry of Education, Culture, Sports, Science and Technology (MEXT) of Japan supplied financial support for this study.

Informed Consent Statement: Not applicable.

Data Availability Statement: The authors confirm that the data supporting the findings of this study are available within the article.

Acknowledgments: The authors would like to thank Harun Yonar for statistical analysis.

Conflicts of Interest: The authors declare no conflict of interest.

\section{References}

1. Uilenberg, G. International collaborative research: Significance of tick-borne hemoparasitic diseases to world animal health. Vet. Parasitol. 1995, 57, 19-41. [CrossRef]

2. Sevinc, F.; Xuan, X. Major tick-borne parasitic diseases of animals: A frame of references in Turkey. Eurasian J. Vet. Sci. 2015, 31, 132-142. [CrossRef]

3. Stuen, S.; Bergstrom, K.; Palmer, E. Reduced weight gain due to subclinical Anaplasma phagocytophilum (formerly Ehrlichia phagocytophila) infections. Exp. Appl. Acarol. 2002, 28, 209-215. [CrossRef]

4. Garcia-Perez, A.L.; Barandika, J.; Oporto, B.; Povedano, I.; Juste, R.A. Anaplasma phagocytophila as an abortifacient agent in sheep farms from northern Spain. Ann. N. Y. Acad. Sci. 2003, 990, 429-432. [CrossRef] [PubMed]

5. Stuen, S. Haemoparasites in small ruminants in European countries: Challenges and clinical relevance. Small Rumin. Res. 2016, 142, 22-27. [CrossRef]

6. Aouadi, A.; Leulmi, H.; Boucheikhchoukh, M.; Benakhla, A.; Raoult, D.; Parola, P. Molecular evidence of tick-borne hemoprotozoan-parasites (Theileria ovis and Babesia ovis) and bacteria in ticks and blood from small ruminants in Northern Algeria. Comp. Immunol. Microbiol. Infect. Dis. 2017, 50, 34-39. [CrossRef] [PubMed]

7. Oluwatayo, I.B.; Oluwatayo, T.B. Small ruminants as a source of financial security: A case study of woman in rural Southwest Nigeria. Inst. Money Technol. Financ. Incl. 2012, 2, 1-21.

8. Turkısh Statistical Institute. Available online: http:/ /www.turkstat.gov.tr/ (accessed on 27 February 2020).

9. Sevinc, F.; Sevinc, M.; Ekici, O.D.; Yildiz, R.; Isik, N.; Aydogdu, U. Babesia ovis infections: Detailed clinical and laboratory observations in the pre- and post-treatment periods of 97 field cases. Vet. Parasitol. 2013, 191, 35-43. [CrossRef] [PubMed] 
10. Alessandra, T.; Santo, C. Tick-borne diseases in sheep and goats: Clinical and diagnostic aspects. Small Rumin. Res. 2012, 106S, S6-S11. [CrossRef]

11. Sparagano, O.A.E.; Spitalska, E.; Namavari, M.; Torina, A.; Cannella, V.; Caracappa, S. Phylogenetics of Theileria species in small ruminants. Ann. N. Y. Acad. Sci. 2006, 1081, 505-508. [CrossRef]

12. Razmi, G.; Pourhosseini, M.; Yaghfouri, S.; Rashidi, A.; Seidabadi, M. Molecular detection of Theileria spp. and Babesia spp. in sheep and ixodid ticks from the northeast of Iran. J. Parasitol. 2013, 99, 77-81. [CrossRef]

13. Renneker, S.; Abdo, J.; Bakheit, M.A.; Kullmann, B.; Beyer, D.; Ahmed, J.; Seitzer, U. Co-infection of sheep with Anaplasma, Theileria and Babesia species in the Kurdistan region, Iraq. Transbound. Emerg. Dis. 2013, 60, 113-118. [CrossRef]

14. Bilgic, H.B.; Bakirci, S.; Kose, O.; Unlu, A.H.; Hacilarlioglu, S.; Eren, H.; Weir, W.; Karagenc, T. Prevalence of tick-borne haemoparasites in small ruminants in Turkey and diagnostic sensitivity of single-PCR and RLB. Parasit. Vectors. 2017, 10, 211. [CrossRef]

15. De la Fuente, J.; Atkinson, M.W.; Naranjo, V.; Fernandez de Mera, I.G.; Mangold, A.J.; Keating, K.A.; Kocan, K.M. Sequnce analysis of the msp4 gene of Anaplasma ovis strains. Vet. Microbiol. 2007, 119, 375-381. [CrossRef] [PubMed]

16. Chochlakis, D.; Koliou, M.; Ioannou, I.; Tselentis, Y.; Psaroulaki, A. Kawasaki disease and Anaplasma sp. infection of an infant in Cyprus. Int. J. Infect. Dis. 2009, 13, e71-e73. [CrossRef]

17. Chochlakis, D.; Ioannou, I.; Tselentis, Y.; Psaroulaki, A. Human anaplasmosis and Anaplasma ovis variant. Emerg. Infect. Dis. 2010, 16, 1031-1032. [CrossRef] [PubMed]

18. Stuen, S. Tick-borne infections in small ruminants in northern Europe. Small Rumin. Res. 2013, 110, 142-144. [CrossRef]

19. Stuen, S.; Granquist, E.G.; Silaghi, C. Anaplasma phagocytophilum- a widespread multi-host pathogen with highly adaptive strategies. Front. Cell. Infect. Microbiol. 2013, 3, 1-33. [CrossRef] [PubMed]

20. Inci, A.; Ica, A.; Yildirim, A.; Duzlu, O. Identification of Babesia and Theileria species in small ruminants in Central Anatolia (Turkey) via reverse line blotting. Turk. J. Vet. Anim. Sci. 2010, 34, 205-210. [CrossRef]

21. Ozubek, S.; Aktas, M. Molecular and parasitological survey of ovine piroplasmosis, including the first report of Theileria annulata (Apicomplexa: Theileridae) in sheep and goats from Turkey. J. Med. Entomol. 2017, 54, 212-220. [CrossRef]

22. Zhou, M.; Cao, S.; Sevinc, F.; Sevinc, M.; Ceylan, O.; Ekici, S.; Jirapattharasate, C.; Moumouni, P.F.A.; Liu, M.; Wang, G.; et al. Molecular detection and genetic characterization of Babesia, Theileria and Anaplasma amongst apparently healthy sheep and goats in the central region of Turkey. Ticks Tick Borne Dis. 2017, 8, 246-252. [CrossRef]

23. Sevinc, F.; Zhou, M.; Cao, S.; Ceylan, O.; Aydin, M.F.; Sevinc, M.; Xuan, X. Haemoparasitic agents associated with ovine babesiosis: A possible negative interaction between Babesia ovis and Theileria ovis. Vet. Parasitol. 2018, 252, 143-147. [CrossRef]

24. Ringo, A.E.; Moumouni, P.F.A.; Taioe, M.; Jirapattharasate, C.; Liu, M.; Wang, G.; Gao, Y.; Guo, H.; Lee, S.; Zheng, W.; et al. Molecular analysis of tick-borne protozoan and rickettsial pathogens in small ruminants from two South African provinces. Parasitol. Int. 2018, 67, 144-149. [CrossRef]

25. De la Fuente, J.; Estrada-Pena, A.; Venzal, J.M.; Kocan, K.M.; Sonenshine, D.E. Overview: Ticks as vectors of pathogens that cause disease in humans and animals. Front. Biosci. 2008, 13, 6938-6946. [CrossRef]

26. Yin, H.; Schnittger, L.; Luo, J.; Seitzer, U.; Ahmed, J.S. Ovine theileriosis in China: A new look at an old story. Parasitol. Res. 2007, 101, S191-S195. [CrossRef] [PubMed]

27. Bai, Q.; Liu, G.; Liu, D.; Ren, J.; Li, X. Isolation and preliminary characterization of a large Babesia sp. from sheep and goats in the eastern part of Gansu Province, China. Parasitol. Res. 2002, 88, S16-S21. [CrossRef] [PubMed]

28. Uilenberg, G. Babesia-A historical overview. Vet. Parasitol. 2006, 138, 3-10. [CrossRef] [PubMed]

29. Liu, A.H.; Yin, H.; Guan, G.Q.; Schnittger, L.; Liu, Z.J.; Ma, M.L.; Dang, Z.S.; Liu, J.L.; Ren, Q.Y.; Bai, Q.; et al. At least two genetically distinct large Babesia species infective to sheep and goats in China. Vet. Parasitol. 2007, 147, 246-251. [CrossRef]

30. Ceylan, O.; Sevinc, F. Endemic instability of ovine babesiosis in Turkey: A country-wide sero-epidemiological study. Vet. Parasitol. 2020, 278, 109034. [CrossRef]

31. Aydin, M.F.; Dumanli, N. Tick-borne pathogens in small ruminants in Turkey: A systematic review. Turk. Vet. J. 2019, 1, 74-83.

32. Aktas, M.; Altay, K.; Dumanli, N. Development of a polymerase chain reaction method for diagnosis of Babesia ovis infection in sheep and goat. Vet. Parasitol. 2005, 133, 277-281. [CrossRef]

33. Altay, K.; Dumanli, N.; Aktas, M. A study on ovine tick-borne hemoprotozoan parasites (Theileria and Babesia) in the East Black Sea Region of Turkey. Parasitol. Res. 2012, 111, 149-153. [CrossRef]

34. Karatepe, B.; Ozubek, S.; Karatepe, M.; Aktas, M. Detection of Theileria and Babesia species in sheep and goats by microscopy and molecular methods in Nigde province, Turkey. Revue Med. Vet. 2019, 170, 136-143.

35. Ahmed, J.; Yin, H.; Bakheit, M.; Liu, Z.; Mehlhorn, H.; Seitzer, U. Small ruminant theileriosis. In Progress in Parasitology; Mehlhorn, H., Ed.; Springer: Düsseldorf, Germany, 2011; Volume 2, pp. 135-154.

36. Friedhoff, K.T. Tick-borne disease of sheep and goats caused by Babesia, Theileria or Anaplasma spp. Parassitologia 1997, 39, 99-109. [PubMed]

37. Altay, K.; Dumanli, N.; Holman, P.J.; Aktas, M. Detection of Theileria ovis in naturally infected sheep by nested PCR. Vet. Parasitol. 2005, 127, 99-104. [CrossRef] [PubMed]

38. Ringo, A.E.; Aboge, G.; Moumouni, P.F.A.; Lee, S.H.; Jirapattharasate, C.; Liu, M.; Gao, Y.; Guo, H.; Zheng, W.; Efstratiou, A.; et al. Molecular detection and genetic characterisation of pathogenic Theileria, Anaplasma and Ehrlichia species among apparently healthy sheep in central and western Kenya. Onderstepoort J. Vet. Res. 2019, 86, a1630. [CrossRef] [PubMed] 
39. Renneker, S.; Abdo, J.; Salih, D.E.A.; Karagenc, T.; Bilgic, H.; Torina, A.; Oliva, A.G.; Campos, J.; Kullmann, B.; Ahmed, J.; et al. Can Anaplasma ovis in small ruminants be neglected any longer? Transbound. Emerg. Dis. 2013, 60, 105-112. [CrossRef] [PubMed]

40. Lbacha, H.A.; Alali, S.; Zouagui, Z.; El Mamoun, L.; Rhalem, A.; Petit, E.; Haddad, N.; Gandoin, C.; Boulouis, H.J.; Maillard, R. High prevalence of Anaplasma spp. in small ruminants in Morocco. Transbound. Emerg. Dis. 2017, 60, 250-263. [CrossRef]

41. Altay, K.; Dumanli, N.; Aktas, M.; Ozubek, S. Survey of Anaplasma infections in small ruminants from east part of Turkey. Kafkas Univ. Vet. Fak. Derg. 2014, 20, 1-4. [CrossRef]

42. Aktas, M.; Ozubek, S. Anaplasma ovis genetic diversity detected by major surface protein 1a and its prevalence in small ruminants. Vet. Microbiol. 2018, 217, 13-17. [CrossRef] [PubMed]

43. Benedicto, B.; Ceylan, O.; Moumouni, P.F.A.; Lee, S.; Li, J.; Galon, E.M.; Liu, M.; Li, Y.; Ji, S.; Tumwebaze, M.A.; et al. Molecular detection and assessment of risk factors for tick-borne diseases in sheep and goats from Turkey. Acta Parasitol. 2020, 65, 723-732. [CrossRef]

44. Oter, K.; Cetinkaya, H.; Vurusaner, C.; Toparlak, M.; Ergunay, K. Molecular detection and typing of Anaplasma species in small ruminants in Thrace Region of Turkey. Kafkas Univ. Vet. Fak. Derg. 2016, 22, 133-138. [CrossRef]

45. Unver, A.; Sahin, M.; Erdogan, H.M.; Celebi, O. Investigation of antibodies against Anaplasma phagocytophilum in sheep by western blot analyses. Kafkas Univ. Vet. Fak. Derg. 2005, 11, 99-102.

46. Gokce, H.I.; Genc, O.; Akca, A.; Vatansever, Z.; Unver, A.; Erdogan, H.M. Molecular and serological evidence of Anaplasma phagocytophilum infection of farm animals in the Black Sea Region of Turkey. Acta Vet. Hung. 2008, 56, 281-292. [CrossRef]

47. Aktas, M.; Vatansever, Z.; Altay, K.; Aydin, M.F.; Dumanli, N. Molecular evidence for Anaplasma phagocytophilum in Ixodes ricinus from Turkey. Trans. R. Soc. Trop. Med. Hyg. 2010, 104, 10-15. [CrossRef] [PubMed]

48. Aktas, M.; Altay, K.; Ozubek, S.; Dumanli, N. A survey of ixodid ticks feding on cattle and prevalence of tick-borne pathogens in the Black Sea region of Turkey. Vet. Parasitol. 2012, 187, 567-571. [CrossRef] [PubMed]

49. Aktas, M. A survey of ixodid tick species and molecular identification of tick-borne pathogens. Vet. Parasitol. 2014, 200, 276-283. [CrossRef] [PubMed]

50. Giangaspero, A.; Marangi, M.; Papini, R.; Paoletti, B.; Wijnveld, M.; Jongejan, F. Theileria sp. OT3 and other tick-borne pathogens in sheep and ticks in Italy: Molecular characterization and phylogeny. Ticks Tick Borne Dis. 2015, 6, 75-83. [CrossRef]

51. Rjeibi, M.R.; Gharbi, M.; Mhadhbi, M.; Mabrouk, W.; Ayari, B.; Nasfi, I.; Jedidi, M.; Sassi, L.; Rekik, M.; Darghouth, M.A. Prevalence of piroplasms in small ruminants in North-West Tunisia and the first genetic characterisation of Babesia ovis in Africa. Parasite 2014, 21, 23. [CrossRef]

52. Aktas, M.; Altay, K.; Dumanli, N. PCR-based detection of Theileria ovis in Rhipicephalus bursa adult ticks. Vet. Parasitol. 2006, 140, 259-263. [CrossRef]

53. Kirvar, E.; Wilkie, G.; Katzer, F.; Brown, C.G.D. Theileria lestoquardi-maturation and quantification in Hyalomma anatolicum anatolicum ticks. Parasitology 1998, 117, 255-263. [CrossRef] [PubMed]

54. Torina, A.; Agnone, A.; Blanda, V.; Alongi, A.; D’Agostino, R.; Caracappa, S.; de la Fuente, J. Development and validation of two PCR tests for the detection of and differentiation between Anaplasma ovis and Anaplasma marginale. Ticks Tick Borne Dis. 2012, 3 , 283-287. [CrossRef]

55. Barlough, J.E.; Madigan, J.E.; DeRock, E.; Dumler, J.S.; Bakken, J.S. Protection against Ehrlichia equi is conferred by prior infection with the human granulocytic ehrlichia (HGE agent). J. Clin. Microbiol. 1995, 33, 3333-3334. [CrossRef] [PubMed]

56. Kawahara, M.; Rikihisa, Y.; Lin, Q.; Isogai, E.; Tahara, K.; Itagaki, A.; Hiramitsu, Y.; Tajima, T. Novel genetic variants of Anaplasma phagocytophilum, Anaplasma bovis, Anaplasma centrale, and a novel Ehrlichia sp. in wild deer and ticks on two major islands in Japan. Appl. Environ. Microbiol. 2006, 72, 1102-1109. [CrossRef] [PubMed] 